\title{
Ringgold County's Centennial
}

\author{
By Luke E. HarT*
}

I know something of the pride with which the people of this county approach this occasion, the celebration of the Centennial of its founding, and "home my footsteps I have turned" in order that I might participate in this historic event.

It is indeed a great privilege for me to be here and to have the opportunity of joining in this celebration, which for me is full of sentiment. It was more than one hundred years ago that my grandfather, Luke Shay, with his wife and three small children settled about three miles west of what is now the town of Tingley, in the northwest quarter of the county, then known as Platte township. It was just one hundred years ago that he joined with other residents in driving "west of Clarinda" some Pottawattamie Indians who were disturbing the tranquility of the settlers. It was just one hundred years ago that the first formal religious services were held in this county of which there is any record or knowledge - a Methodist service in Mount Ayr and the celebration of Mass in my grandfather's home by a Catholic priest who had arrived there on mule back while he and his wife and their children were accompanying other residents of the county on the trip to drive the Indians "west of Clarinda."

It was just one hundred years ago this coming December that his son Thomas S. Shay was born, the first

- Address of Luke E. Hart at Mount Ayr, Iowa, July 4, 1955, on occasion of the Centennial celebration of organization of Ringgold county. Mr. Hart, a native of Maloy in that county, was long a practicing attorney at St. Louis, Missouri, and is now Supreme Knight of the fraternal order of Knights of Columbus with headquarters at New Haven, Connecticut. From 1922 to 1953, he served as Supreme Advocate of the order, in which capacity he acted as legal counsel and its key policy-maker. Since his advancement to the high position of Supreme Knight, he has been chief administrative officer in the organization. For many years he has been the recognized strategist behind its growth, official policies and manifold programs. 
white child born in Platte township, embracing the entire northwest quarter of the county. It lacks just two of being one hundred years since the district court of Ringgold county, as its first act following its establishment, granted his petition for citizenship.

My grandfather, whose name I bear, exerted a great influence over my life. $\mathrm{He}$ was a deeply patriotic American. He belonged to that group of men who pushed the frontiers of this nation beyond the Mississippi river and into a new and wholly undeveloped territory. He had pride of ancestry and he deeply revered his forebears, his father, his grandfather and his great grandfather, whose graves I have visited and over the latter of which may be found today, a monument stating that "Here lyeth the body of Luke Shea, born 1705, died 1762."

To me his life symbolizes the spirit of our nation. As a young Irish immigrant of twenty-four, he arrived with his wife at Castle Garden in New York harbor in the year 1848. After five years of work on the railroads, from New York to Baltimore, to Louisville, to Terre Haute, he, with his wife and two small children, and $\$ 360$ which he had saved, arrived in this vicinity in the spring of 1852. After a year in Union county, he purchased the land west of Tingley in Ringgold county which afterward became his home.

But circumstances in the form of a prairie fire which destroyed his home in Union county and compelled his removal to Clark and then to Decatur counties, delayed his taking up his residence on the farm near Tingley until the early spring of 1855 . But from that day until his death, forty-one years later, Ringgold county was his home and the scene of all of his activities. $\mathrm{He}$ gained his livelihood by farming and stock raising. His activities were confined largely to the western part of the county. One of the early historians of Ringgold county, comparing another of the early pioneers, Andrew O. Ingram, with him, said, "He was to the eastern 
part of the county what Luke Shay was to the western part of the county."

He was a devout Christian. He practiced his religion faithfully and without ostentation. In the very early days, when facilities for the performance of his religious duties were not close at hand, he took three of his children, in their turn-my mother in 1853, my Uncle Thomas S. Shay in 1855 and my Uncle Douglas Shay in 1857 - by moving wagon to St. Joseph, Missouri, one hundred miles away, without roads, without bridges and a week's journey, in order that they might be baptized in accordance with the tenets of his religion.

That spirit of enterprise, that vision, that industry and that rugged determination were characteristic of the men and women who founded this county and established it as one of the units that make this one of the greatest states in the Union.

I relate these facts with regard to my own pioneer ancestors for the purpose of bringing home to those in the audience the circumstances under which this new county was populated and developed. However, I realize that they are merely typical because there are few Americans who cannot find in their family history similar stories of those who risked much and endured much to bring a dream into reality. It is those qualities which within the short span of one hundred years have developed this great community and have made this into the greatest nation on earth.

Ringgold County Opened for Setrlement

I know the question arises in the minds of many as to why lowa, and in particular, Ringgold county, was so late in its development. The fact is that until the Black Hawk war of 1832, which was fought on the east bank of the Mississippi river, all of Iowa belonged to the Indians. But as a part of the settlement that grew out of that war, a strip about ninety miles wide along the west side of the Mississippi river, and containing about six million acres, became the property of the United States and was opened for settlement on June 
1, 1833. Thereafter the state was opened by sections and it was not until May, 1843, that Ringgold county was opened for settlement.

With the cession of the six million acre tract on the west bank of the Mississippi river, the area was divided into two counties, Dubuque county on the north and De Moine county on the south. Development proceeded rapidly and in August, 1836, Dubuque county had a population of 4,274 and De Moine county a population of 10,531. Two years later the population had almost doubled, with 22,859 people in the sixteen counties that were organized from the area comprising the two original counties. This rate of growth continued and census taken in 1840 found the population to be 43,112 .

In his message to the legislature upon its convening at Burlington, November 9, 1839, Governor Lucas said that with a genial climate, soil unsurpassed for fertility, abounding with pure water, navigable rivers and inexhaustible mineral resources, it had advanced, since its organization, in improvement, population and wealth beyond a parallel in all previous experience and he recommended that the legislature formally request the congress to authorize the admission of Iowa as a state at an early date. By mid-summer of 1844, it was estimated that the population numbered over 75,000 . That was the year Ringgold county acquired its first settler, when Charles H. Schooler settled in the southeastern part of the county.

When Iowa was admitted as a state in 1846, the first free state carved out of the Louisiana territory, its population was slightly more than 100,000 . It had 44 counties, mostly in the southeastern corner of the state, where most of its population then resided. Fewer than 10,000 resided in northern Iowa and there were but two families in Ringgold county, the family of James Tithrow having settled near that of Charles H. Schooler in the summer of 1846. The first white child born in the county was Manoah B. Schooler, who was born in 1847.

There was no further settlement for several years 
and in 1854 there were only nine families in the county. However, in 1855 there was quite a brisk migrationfour or five neighborhoods being formed in different parts of the county. It seems strange, indeed, that Iowa should have waited so long-340 years after Columbus discovered America and 212 years after the Pilgrims landed at Plymouth Rock.

\section{Attractiveness of Iowa Country}

When the settlers did come to Iowa, they beheld the most attractive and the most inviting country ever fashioned by the Creator. It was a broad undulating prairie, rising gradually from the southeast corner, where its lowest point is 444 feet above sea level, toward the northwest, where in the northwest part of the state the highest point is 1,694 feet above sea level, a land bounded on the east by the broad Mississippi and on the west by the mighty Missouri.

And what brought these people to Iowa and to Ringgold county? All of the great events of history, the struggles and tumults, the victories and defeats of which there is a record, are merely incidents of an irresistible tendency to movement among human beings. That movement of races no system of political organization and no form of government, however powerful or extensive, has been able to arrest or even to check. And that movement of races has always been the result of land hunger, of an impelling demand for new lands to provide sustenance for those mouths which could no longer find it on the lands they occupied.

It was this hunger for land that moved Barbarian tribes to invade the Roman province, overturn the empire and wreck the monuments of ancient civilization. It was that same hunger that plunged the nations of the earth into two world holocausts and keeps them now teetering on the brink of still another. While this soil has been the theater of a race movement greater than any the world has ever seen, it has involved no violence and entailed no injury to anyone, but has brought enormous benefits to millions. 
The pioneer settlers of Ringgold county found here a country that was nearly all prairie, excepting the valleys of the Platte river, along its western boundary, and the several forks of the Grand river and their affluents. The soil was covered with native grasses and in the valleys there was sufficent timber for the erection of temporary buildings, for fuel and for rails for fences and the protection of their crops. The streams abounded with fish and there was an abundance of game, including buffalo, deer, wolves, squirrels, prairie chickens and quail, passenger pigeons, ducks and geese.

This was the country into which came the pioneer settlers whose deeds and accomplishments we have gathered here to commemorate. They did not come here to seek a life of ease. Their coming was a determined and carefully considered choice. They wanted a place where they could have peace, where they could rear their families in the love and fear of God, where their children could be educated and where by industry and thrift they might earn a competence to sustain them in their declining years.

\section{LAND SOUGHT FOR HoMES}

From the very beginning, the home has been the fundamental unit of the social order in this country and our government has encouraged the homemaking spirit among its citizens. First, it allotted public lands to those who would settle on them, live there a number of years and improve them as homesteads. The laws preserve free from sale for debt, certain homesteads of our citizens. The laws of various states exempt from taxation owner-occupied homes, household goods and tools of trade of the head of a home. The federal and state governments allow deductions for income tax purposes for wives and children. Generally, the farmers in the field, the miners in the bowels of the earth, the business and professional men in their shops and offices, the workers in the factories are working to earn money with which to establish and maintain homes - homes to house their families and in which 
to rear and educate their children. Without homes there would be no social order, no schools, no churches and no American way of life as we know it in this country.

The men and women who came to Ringgold county had no illusions as to what frontier life on a western prairie would require of them. They were under the stern pressure of making a livelihood. They came with a knowledge that the privileges they hoped to acquire involved the assumption of burdens. There was nothing about them to awaken friendly interest among those with whom they came in contact excepting their moral character, their ability and their willingness to contribute by their efforts to the establishment of a new community. They brought with them the most valuable possession that any man could offer - a pair of human hands and an eagerness to employ themselves in the cultivation of the soil. They believed in the admonition of the Creator that man must earn his bread by the sweat of his brow. They were able to work and willing to work, and so they went to work. In season and out of season they labored, the women with the men.

They were without money to spend, but that made little difference because there was nothing to buy. The nearest trading points were St. Joseph, Missouri, Keokuk and Burlington, each 100 miles away - a week's journey in a moving wagon. There were no roads, but that did not matter because there was no place to go. The only vehicle was the wagon which brought them, their families and their possessions. There were no electric lights, not even coal oil lamps; only home-made tallow candles. There were no stoves; only open grate fires. There were no washing machines; only wash boards, and not many of these.

They raised and sheared their own sheep, carded and spun the wool, wove the cloth, knitted the yarn and otherwise fashioned their clothing. Their houses were not merely places in which to live. They were work- 
shops and factories in which the things needed for their livelihood and comfort were planned and made.

\section{EnForcement of Citrzens' Rights}

There were no courts but they were scarcely needed, because each one respected the other's rights. The only serious transgression of another's rights occurred when a man just over the line in Decatur county became angry because a neighbor's cow had damaged his corn and he shot and killed the owner of the cows. These sturdy pioneer ancestors of ours formed a posse, took the guilty party in hand, organized themselves into a court, heard the testimony of witnesses, found him guilty, sentenced him to be shot and, on the four corners at the intersection of Ringgold, Decatur, Clarke and Union counties, proceeded to carry out the sentence.

There were no tractors and only a few horses. Nearly all heavy work was done with oxen. Almost the only implements now in use on the farm that were then known to these early pioneers were the pitchfork and the plow, and the plow of the early 50's was a crude implement, indeed. The soil was sod-bound and tough and it was a considerable undertaking to break the ground on 40 acres or 80 acres with one of these early. plows and a yoke, or several yoke, of oxen.

I remember hearing Thomas Canny, one of the very early pioneers and a man who became one of the county's most prosperous and respected citizens, relate an incident that may be worth repeating here. During the winter of 1855-56, he and two other men were engaged in hauling logs for my grandfather on three sleds, with several yoke of oxen. It was bitter cold and Mr. Canny and one of the other men thought it necessary to walk in order to keep their blood circulating and thus avoid freezing. But the third man insisted upon riding on his load of logs. Mr. Canny and the other man used their ox whips on the fellow who wanted to ride, which made him so angry that he would run after them, but in this way they kept him moving and thus prevented his freezing to death. 
I have often heard my grandmother tell of the founding of their first home in the Tingley vicinity. The simplest structure that could be built was the stable for the horses and it was built first. But the members of the family were in greater need of shelter than the horses and, therefore, when the stable was finished, it was occupied by the family until the house was erected, and not until the house was finished and the family had moved in was the stable made available for the horses. In the meantime, cooking and other household work that required the use of a fire was done outdoors over an open fire.

\section{Iowa's SetTlement and Growth}

It is an historical fact that the greatest movement for the settlement of a new country that ever occurred in the history of the world took place here in Iowa between 1840 and 1860, and although the movement began in Ringgold county later than it did in the counties farther east and north, by the middle of 1855 it was in full swing here.

At first, what is now Ringgold county was attached to Taylor county. In the spring of 1851, commissioners appointed by act of the legislature to locate the seat of justice for Ringgold county reported that they had selected a place for the county seat, which they had designated by setting a stake about four miles south of the center of the county and that they had named the said county seat Urbana. They gave as a reason for their inability to give a more particular description of the place the fact that the land had not been surveyed into sections. I suspect that at this time nobody knows the exact location of Urbana. This first attempt to organize the county was not a success, probably due to the fact that there was not sufficient population to form an organization.

October 16, 1852, the county judge of Taylor county entered an order declaring Ringgold county to be a separate election precinct under the name of Schooler township and designating the voting place for the presi- 
dential election to be the house of Lott Hobbs, in the southern part of the county. The creek in that vicinity known as Lott's creek derived its name from Mr. Hobbs and the township derived its name from both.

\section{Mount Ayr Located as County Seat}

April 18, 1855, commissioners appointed by act of the legislature to locate the county seat of Ringgold county reported to the county judge of Decatur county, as the act of the legislature provided, that they had selected for the county seat the southwest quarter of Section 6 , Township 68, Range 29, with the name Mount Ayr, and on June 9, 1855, Edward A. Temple deeded the land to the county.

At the election that was held soon thereafter, James C. Hagans was elected county judge, Matthew $\mathbf{R}$. Brown, clerk, Joseph W. Cofer, treasurer and recorder, Hiram Imus, sheriff, and Charles H. Schooler, school fund commissioner, and on June 29, 1855, Judge Hagans made a settlement of financial matters with Judge Lowe of Taylor county whereby he received $\$ 1.45$ that was due Ringgold county, and with this small capital Ringgold county set up for itself.

The first formal meeting of the county officers was held at the house of Ephraim Cofer, about six miles south of Mount Ayr, July 2, 1855. At that time the county judge divided the county into four townships, or election precincts, respectively, Sand Creek, Platte, West Fork and Lotts Creek, and it was ordered that an election be held on the first Monday in August at the homes of Stanberry Wright for the northeast precinct, Garret Bird for the northwest precinct, John McGaughey for the southwest precinct and Joseph Strickland for the southeast precinct. The county judge, clerk and recorder divided the fees they had received up to that date and the share of each one amounted to $\$ 5.20$.

The public business continued to be transacted at the home of Ephraim Cofer until September, 1855, when it was transferred to Mount Ayr. In the spring of 1856, the county judge caused to be erected at Mount Ayr a 
hewn log house for the use of the county officers. It was 14 feet square, furnished with two tables, two desks, four bookcases and a small rough-board box or safe for the public revenue. This building was occupied by the county judge, clerk, treasurer, surveyor and one physician.

This first courthouse was superseded in 1859 by a frame one that was erected on the east side of, and which fronted, the public square. It was two stories in height, with four office rooms on the first floor and court and jury rooms on the second floor. It cost $\$ 3,500$, which was paid from the proceeds of the sale of town lots.

The first district court for Ringgold county convened in Mount Ayr, May 25, 1857, with Judge John S. Townsend presiding, Randolph Spry as clerk and John W. Warren as prosecuting attorney, and the first business transacted by the court was the granting of the application of my grandfather, Luke Shay, for naturalization as a citizen.

The most prominent man in the early history of the county was Judge Hagans, who was born in Kentucky and came here from $\mathrm{McD}$ onough county, Illinois. After serving three terms as county judge, he was elected a state senator and served with distinction in the Eighth and Ninth general assemblies. He died September 7, 1863, at his home in Mount Ayr.

Churches Early in Establishment

The pioneers of Ringgold county were good Christian, God-fearing people. Many of them brought a surprising number and variety of books but almost without exception they brought with them at least one book, the Bible. Through it all they remained loyal to the religious teachings and precepts of their forefathers. Throughout the county, religious services were conducted in the schoolhouses. Later, chapels devoted exclusively to the worship of Almighty God were built in different parts of the county. Among these was the Fry Chapel several miles south of Mount Ayr, which, I be- 
lieve, is still in use. Another was the Highland Chapel about five miles west of Benton. But with the establishment of the towns and the improvement of the roads and travel conditions, churches were built in the towns and many of the country chapels were discontinued.

Today, every town and village in the county has one or more churches, with Mount Ayr having several fine churches and each one having pious and devoted congregations. There has never been any rivalry between the different religious groups in this county and therefore there is no bigotry, no intolerance and no discrimination. Each group and each member in each group serves the Master in accordance with the dictates of his own conscience and each one accords to his neighbor the full right to exercise that same privilege.

There is some question as to the exact date and location of the first school within the confines of this county, but it is certain that several schools were started between the years 1854 and 1858-not less than three or four. There are many supporters for the claim that each of these was first, but I do not think we can undertake to settle those claims here. However, it is certain that at about that time schools were built in Jefferson township, possibly as early as 1854, and in Mount Ayr as early as the winter of 1855-56. Early teachers were Miss Arsella Kirkham, John Cunningham, a Miss Brown, Miss Bell and Miss Charlotte Swan, whose wages varied from four dollars per month to ten dollars per month.

Then came the system of establishing district schools two miles apart. There were no school buses and as I was among those who happened to live diagonally across a section from the school, during my early childhood I walked two miles to school. The advancement in the Iowa school system has been one of the marvels in the development of our nation's educational system. The consolidated grade and high schools, the normal schools, junior colleges and universities in Iowa outrank those of any other state in the Union and the ex- 
penditure per capita of schools in Iowa is many times as great as it is in some of the other states.

Throughout all of these now more than one hundred years since the settlement of Ringgold county began, the people of this county, together with other people of this great state, have given of their manhood and their womanhood to the upbuilding of communities of which every Iowan is proud. From out the homes they established have gone boys and girls to give this nation strength and to make it worthy of the great heritage that is ours. No limitation of race or tongue or creed has interfered with the free interchange of talents, the merging of ideals and the development of that creative spirit that has given America its place of leadership among the nations of the earth. That Ringgold county and Iowa have contributed more than their share toward all of this is a matter of common knowledge and it can easily be demonstrated.

\section{Contributed to Defense of Nation}

The people of Ringgold county have always exhibited a fine spirit of patriotism and have contributed generously to every national endeavor. When the Civil war broke out and the safety of the Union was threatened, the response of Iowa to the call of President Lincoln for volunteers was overwhelming. Although the population of the state was less than 700,000-including not more than 150,000 men eligible for service-Iowa gave to the Union army 75,519 volunteers. Every cemetery in Ringgold county enshrines the remains of men who served their country in the defense of the Union. Also in the Spanish-American war, in the first and second World wars and in the Korean episode, Ringgold county did its full share.

What Ringgold county did to vindicate the honor of our nation in the second World war is very fresh in our memories. Here is the record: Ringgold county contributed to the armed service of our country 1,045 men and 19 women. Theirs is a glorious record and proves them to be worthy of the best traditions of our soldiers 
in other wars. They have returned, all but 45 of the dearest and best of them, who made the supreme sacrifice and who will never return. Their sacrifices and the record of their deeds will be held in grateful memory as long as time shall last.

America has always upheld the principles asserted in the Declaration of Independence and established with the blood and the sacrifice of our founding fathers in the war of the Revolution. It was to uphold those principles that two world wars were fought and the boys from Ringgold county who endured the hardships and made the sacrifices that the war required of our armed forces were valiant and loyal successors of the hardy pioneers who one hundred years ago established this great community in which you live and of which every person having any relationship to Ringgold county is proud.

Permit me again to extend my sincere thanks for the honor and privilege of being here and having a part in this program. In a busy life, crowded with activities that absorb my time and energies, this manifestation of your friendship and good will will be treasured by me among my choicest memories.

\section{TV Sets Outstrip Bathtubs}

Farm homes in Iowa have fast become modern-and the new ones have the conventional conveniences. But word now comes that in one county at least there are now more television sets than bathtubs. It seems there are 2,329 farm homes in Polk county in which 1,769 have bathtubs and running water. But there are 1,788 of the farm homes of the county having television sets.

Other records show that in Polk county farm homes there are 2,093 telephones. 2,274 farmers have electricity, 2,063 have automobiles, and on 1,360 of these farms are neither horses nor mules. 
Copyright of Annals of Iowa is the property of State of Iowa, by \& through the State Historical Society of Iowa and its content may not be copied or emailed to multiple sites or posted to a listserv without the copyright holder's express written permission. However, users may print, download, or email articles for individual use. 